\title{
Front Matter: Volume 9189
}

"Front Matter: Volume 9189," Proc. SPIE 9189, Photonic Innovations and Solutions for Complex Environments and Systems (PISCES) II, 918901 (16 September 2014); doi: 10.1117/12.2085340

SPIE Event: SPIE Optical Engineering + Applications, 2014, San Diego, California, SPIE. United States 


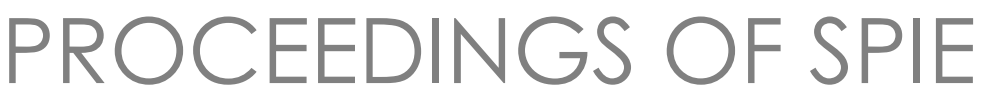

\title{
Photonic Innovations and Solutions for Complex Environments and Systems (PISCES) II
}

\author{
Akhlesh Lakhtakia \\ Judith A. Todd \\ Editors
}

17 August 2014

San Diego, California, United States

Sponsored and Published by

SPIE 
The papers included in this volume were part of the technical conference cited on the cover and title page. Papers were selected and subject to review by the editors and conference program committee. Some conference presentations may not be available for publication. The papers published in these proceedings reflect the work and thoughts of the authors and are published herein as submitted. The publisher is not responsible for the validity of the information or for any outcomes resulting from reliance thereon.

Please use the following format to cite material from this book:

Author(s), "Title of Paper," in Photonic Innovations and Solutions for Complex Environments and Systems (PISCES) II, edited by Akhlesh Lakhtakia, Judith A. Todd, Proceedings of SPIE Vol. 9189 (SPIE, Bellingham, WA, 2014) Article CID Number.

ISSN: 0277-786X

ISBN: 9781628412161

Published by

SPIE

P.O. Box 10, Bellingham, Washington 98227-0010 USA

Telephone +1 3606763290 (Pacific Time) · Fax +1 3606471445

SPIE.org

Copyright @ 2014, Society of Photo-Optical Instrumentation Engineers.

Copying of material in this book for internal or personal use, or for the internal or personal use of specific clients, beyond the fair use provisions granted by the U.S. Copyright Law is authorized by SPIE subject to payment of copying fees. The Transactional Reporting Service base fee for this volume is $\$ 18.00$ per article (or portion thereof), which should be paid directly to the Copyright Clearance Center (CCC), 222 Rosewood Drive, Danvers, MA 01923. Payment may also be made electronically through CCC Online at copyright.com. Other copying for republication, resale, advertising or promotion, or any form of systematic or multiple reproduction of any material in this book is prohibited except with permission in writing from the publisher. The CCC fee code is 0277-786X/14/\$18.00.

Printed in the United States of America.

Publication of record for individual papers is online in the SPIE Digital Library.

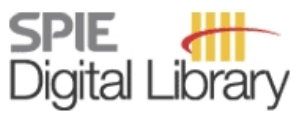

SPIEDigitalLibrary.org

Paper Numbering: Proceedings of SPIE follow an e-First publication model, with papers published first online and then in print and on CD-ROM. Papers are published as they are submitted and meet publication criteria. A unique, consistent, permanent citation identifier (CID) number is assigned to each article at the time of the first publication. Utilization of CIDs allows articles to be fully citable as soon as they are published online, and connects the same identifier to all online, print, and electronic versions of the publication. SPIE uses a six-digit CID article numbering system in which:

- The first four digits correspond to the SPIE volume number.

- The last two digits indicate publication order within the volume using a Base 36 numbering

system employing both numerals and letters. These two-number sets start with 00, 01, 02, 03, 04, 05, 06, 07, 08, 09, 0A, 0B ... 0Z, followed by 10-1Z, 20-2Z, etc.

The CID Number appears on each page of the manuscript. The complete citation is used on the first page, and an abbreviated version on subsequent pages. Numbers in the index correspond to the last two digits of the six-digit CID Number. 


\title{
Contents
}

\author{
$\checkmark$ Authors \\ vii Conference Committee
}

\section{SESSION 1}

918905 From research to product: a complex pathway [9189-4]

SESSION 2

918908 Medical imaging and computers in the diagnosis of breast cancer [9189-6]

918909 Silicon carbide novel optical sensor for combustion systems and nuclear reactors [9189-7]

\section{SESSION 3}

9189 0C The Schmidt-Czerny-Turner spectrograph [9189-10]

9189 OD Line-edge roughness and the impact of stochastic processes on lithography scaling for Moore's law [9189-11]

$9189 \mathrm{OE}$ Technological innovations for a sustainable business model in the semiconductor industry [9189-12]

\section{SESSION 4}

9189 OF Sun-, earth- and moon-integrated simulation ray tracing for observation from space using ASAP [9189-13] 
Proc. of SPIE Vol. $9189918901-4$

Downloaded From: https://www.spiedigitallibrary.org/conference-proceedings-of-spie on 26 Apr 2023 Terms of Use: https://www.spiedigitallibrary.org/terms-of-use 


\section{Authors}

Numbers in the index correspond to the last two digits of the six-digit citation identifier (CID) article numbering system used in Proceedings of SPIE. The first four digits reflect the volume number. Base 36 numbering is employed for the last two digits and indicates the order of articles within the volume. Numbers start with 00, 01, 02, 03, 04, 05, 06, 07, 08, 09, 0A, 0B...0Z, followed by 10-1Z, 20-2Z, etc.

Breault, Robert P., OF

Flory, François R., 05

Giger, Maryellen L., 08

Kar, Aravinda, 09

Kim, Sug-Whan, OF

Levinson, Harry J., OE

Lim, Geunsik, 09

Mack, Chris A., OD

McClure, Jason P., OC

Mirochnitchenko, Katia, 05

Ryu, Dongok, OF

Yang, Seul-Ki, OF

Proc. of SPIE Vol. $9189918901-5$ 
Proc. of SPIE Vol. $9189918901-6$

Downloaded From: https://www.spiedigitallibrary.org/conference-proceedings-of-spie on 26 Apr 2023 Terms of Use: https://www.spiedigitallibrary.org/terms-of-use 


\title{
Conference Committee
}

\author{
Conference Chairs
}

Akhlesh Lakhtakia, The Pennsylvania State University (United States) Judith A. Todd, The Pennsylvania State University (United States)

Session Chairs

1 Session 1

Akhlesh Lakhtakia, The Pennsylvania State University (United States)

Judith A. Todd, The Pennsylvania State University (United States)

2 Session 2

Akhlesh Lakhtakia, The Pennsylvania State University (United States)

Judith A. Todd, The Pennsylvania State University (United States)

3 Session 3

Judith A. Todd, The Pennsylvania State University (United States)

Akhlesh Lakhtakia, The Pennsylvania State University (United States)

4 Session 4

Judith A. Todd, The Pennsylvania State University (United States)

Akhlesh Lakhtakia, The Pennsylvania State University (United States) 
Proc. of SPIE Vol. $9189918901-8$

Downloaded From: https://www.spiedigitallibrary.org/conference-proceedings-of-spie on 26 Apr 2023 Terms of Use: https://www.spiedigitallibrary.org/terms-of-use 